Matematikai Közlemények

III. kötet, 2015

doi:10.20312/dim.2015.04

\title{
Időjárás elemzés regressziós eljárás alkalmazásával
}

\author{
Csanády Viktória \\ NyME, EMK Matematikai Intézet \\ csanady.viktoria@emk.nyme.hu
}

\begin{abstract}
ÖSSZEFOGLALÓ. Napjaink egyik legégetőbb és egyben legfontosabb kutatási témája a klímaváltozás. Számos vélemény, kutatási eredmény lát napvilágot e témában, melyek gyakran bonyolult meteorológiai modellek alkalmazásaiból számítottak. Az alábbiakban tényleges mért hőmérsékleti adatok kielemzésére kerül sor egyváltozós regressziós modellek által, melyek paraméterei fizikailag jól értelmezhetők. Az alkalmazott modellek lehetőséget adnak éves hőmérsékleti adatok összehasonlítására, alapvető különbségek kimutatására.
\end{abstract}

ABSTRACT. Temperature data will be analysed by univariate regression models. The parameters of models can be interpreted well physically. Applied models allow comparison of annual temperature data.

\section{Bevezetés}

Ismert tény, hogy az utóbbi évtizedekben számos alkalommal voltak megfigyelhetők időjárási anomáliák, melyek gyakorisága növekvő tendenciát mutat, szélsőségességük mértéke pedig növekszik. Ezen tények ismeretében felmerült a kérdés, miként mutathatók ki egyszerübb matematikai statisztikai vizsgálatok alkalmazása révén a különbségek, és ezek milyen paraméterekkel jellemezhetők.

\section{Anyag és módszer}

A vizsgálat tárgyát 3 esztendő, nevezetesen a 2012, 2013 és 2014. évi Budapesten mért hőmérsékleti adatok jelentették. A vizsgálathoz felhasználásra került a napi maximális, napi minimális hőmérséklet, valamint az ezen értékekből képzett maximum-minimum hőmérsékleti érték különbsége, vagyis a napi hőmérsékleti differencia. Az éves adatsorok összehasonlításra alkalmas elemzése, a vizuális lehetőség kihasználása érdekében is, regressziós eljárással történt, megfelelö függvény kiválasztásával.

\section{Eredmények kiértékelése}

\subsection{Kezdő vizsgálat}

A rendelkezésre álló adatok jellegének áttekintése alapján a kiválasztandó függvénynek rendelkeznie kell maximummal, a közelítő szimmetria miatt két inflexiós ponttal, és szükséges, hogy felülről és alulról is korlátos legyen. Ezen túlmenően paraméterei legyenek közvetlenül értelmezhetők, és darabszámuk minél több közvetlen vagy közvetett információt adjon. 
Ezek alapján közelítő "Gauss-görbe" látszik szükségesnek, minek megfelelően az alábbi két függvényalak alkalmazható.

A függvény görbületi jellege állandó a 2-es hatványkitevő miatt:

$$
\text { 1. } \quad \operatorname{var} 2=\mathrm{b} 3 / \exp \left(\mathrm{b} 2 *(\operatorname{var} 1-1 * \mathrm{~b} 1)^{\wedge} 2\right)+\mathrm{b} 0 \text {. }
$$

A függvény görbületi jellege változó a b1 hatványkitevő miatt:

$$
\text { 2. } \quad \operatorname{var} 2=b 4 / \exp \left((b 3 *(\operatorname{abs}(\operatorname{var} 1-1 * b 2)))^{\wedge} \mathrm{b} 1\right)+b 0 \text {. }
$$

Mindkét függvény függőlegesen és vízszintesen nyújtott és eltolt a szükségnek megfelelően, és paramétereiről közvetlenül leolvasható a felső és alsó korlát, a maximum helye és értéke, és a 2. függvénynél a görbület jellege. A megadott adatsorokon történt alkalmazás során pedig egyértelmüen kiderült, hogy a 2. függvény illesztésénél minden esetben a kapott korrelációs együttható $(\mathrm{R})$ jobb, mint az 1 . függvénynél, ezért a 2 . függvény alkalmazására került sor.

\begin{tabular}{|c|c|c|c|c|c|}
\hline \multirow[b]{2}{*}{$\mathrm{N}=365$} & \multicolumn{5}{|c|}{$\begin{array}{l}\text { Model: var8=b4/exp }\left(\left(b^{\star}\left(a b s\left(\operatorname{var} 1-1^{*} \mathrm{~b} 2\right)\right)\right)^{\wedge} \mathrm{b} 1\right)+\mathrm{b} 0(2012 \mathrm{hö}) \\
\text { Dep. var: VAR8 Loss: }(\mathrm{OBS}-\mathrm{PRED})^{\star \star} 2 \\
\text { Final loss: } 1342,3410890 \mathrm{R}=, 83918 \text { Variance explained: } 70,423 \%\end{array}$} \\
\hline & \begin{tabular}{|l|}
$\mathrm{b} 4$ \\
\end{tabular} & b3 & b2 & b1 & b0 \\
\hline Estimate & 7,862376 & 0,008015 & 181,1240 & 4,233503 & 3,894965 \\
\hline
\end{tabular}

A számított eredményeket és értékeket az alábbi táblázatok és grafikonok mutatják.

\begin{tabular}{|c|c|c|c|c|c|}
\hline \multirow[b]{2}{*}{$N=365$} & \multicolumn{5}{|c|}{$\begin{array}{l}\text { Model: var5=b4/exp }\left(\left(\mathrm{b} 3^{*}\left(\mathrm{abs}\left(\operatorname{var} 1-1^{*} \mathrm{~b} 2\right)\right)\right)^{\wedge} \mathrm{b} 1\right)+\mathrm{b} 0(2012 \mathrm{hő}) \\
\text { Dep. var: VAR5 Loss: (OBS-PRED)**2 } \\
\text { Final loss: } 6686,8264727 \mathrm{R}=, 92447 \text { Variance explained: } 85,464 \%\end{array}$} \\
\hline & b4 & b3 & b2 & b1 & $\mathrm{b0}$ \\
\hline Estimate & 28,50690 & 0,008402 & 197,7722 & 3,235200 & $-0,493745$ \\
\hline
\end{tabular}

1. táblázat: Hőmérsékleti differencia 2012

\begin{tabular}{|c|c|c|c|c|c|}
\hline \multirow[b]{2}{*}{$N=365$} & \multicolumn{5}{|c|}{$\begin{array}{l}\text { Model: var6=b4/exp }\left(\left(b 3^{\star}\left(\mathrm{abs}\left(\operatorname{var} 1-1^{\star} \mathrm{b} 2\right)\right)\right)^{\wedge} \mathrm{b} 1\right)+\mathrm{b} 0(2012 \mathrm{hő}) \\
\text { Dep. var: VAR6 Loss: (OBS-PRED)**2 } \\
\text { Final loss: } 5016,2605706 \mathrm{R}=, 89887 \text { Variance explained: } 80,797 \%\end{array}$} \\
\hline & $\mathrm{b} 4$ & b3 & b2 & b1 & b0 \\
\hline Estimate & 21,27165 & 0,008540 & 204,4272 & 2,897582 & $-4,75227$ \\
\hline
\end{tabular}

2. táblázat: Hőmérsékleti maximum 2012

3. táblázat: Hőmérsékleti minimum a 2012 


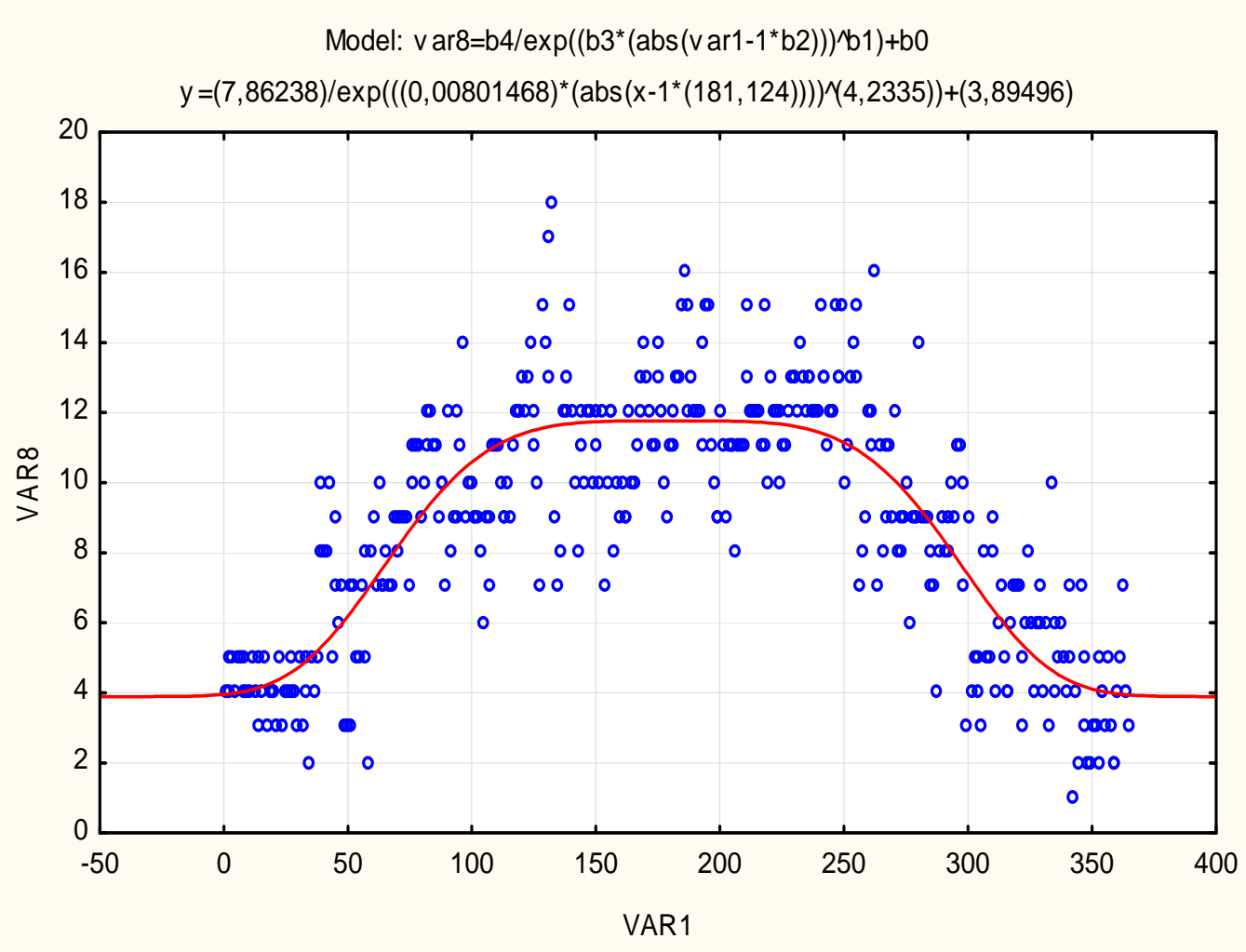

1. ábra: Hőmérsékleti differencia 2012

Model: $\operatorname{var} 5=b 4 / \exp \left(\left(b 3^{*}\left(\operatorname{abs}\left(\operatorname{var} 1-1^{*} \mathrm{~b} 2\right)\right)\right) \wedge \mathrm{b} 1\right)+\mathrm{b} 0$

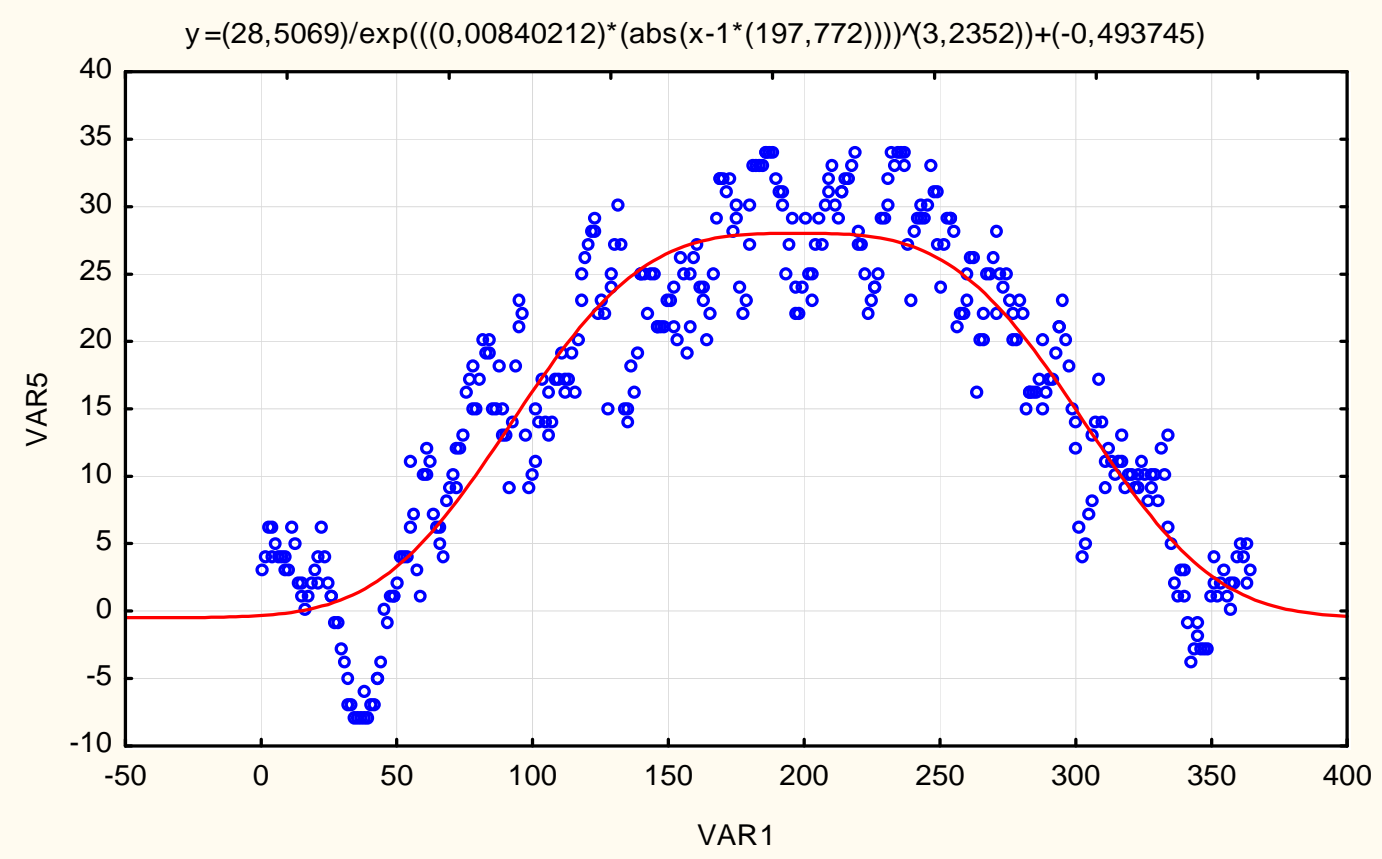

2. ábra: Hőmérsékleti maximum 2012 


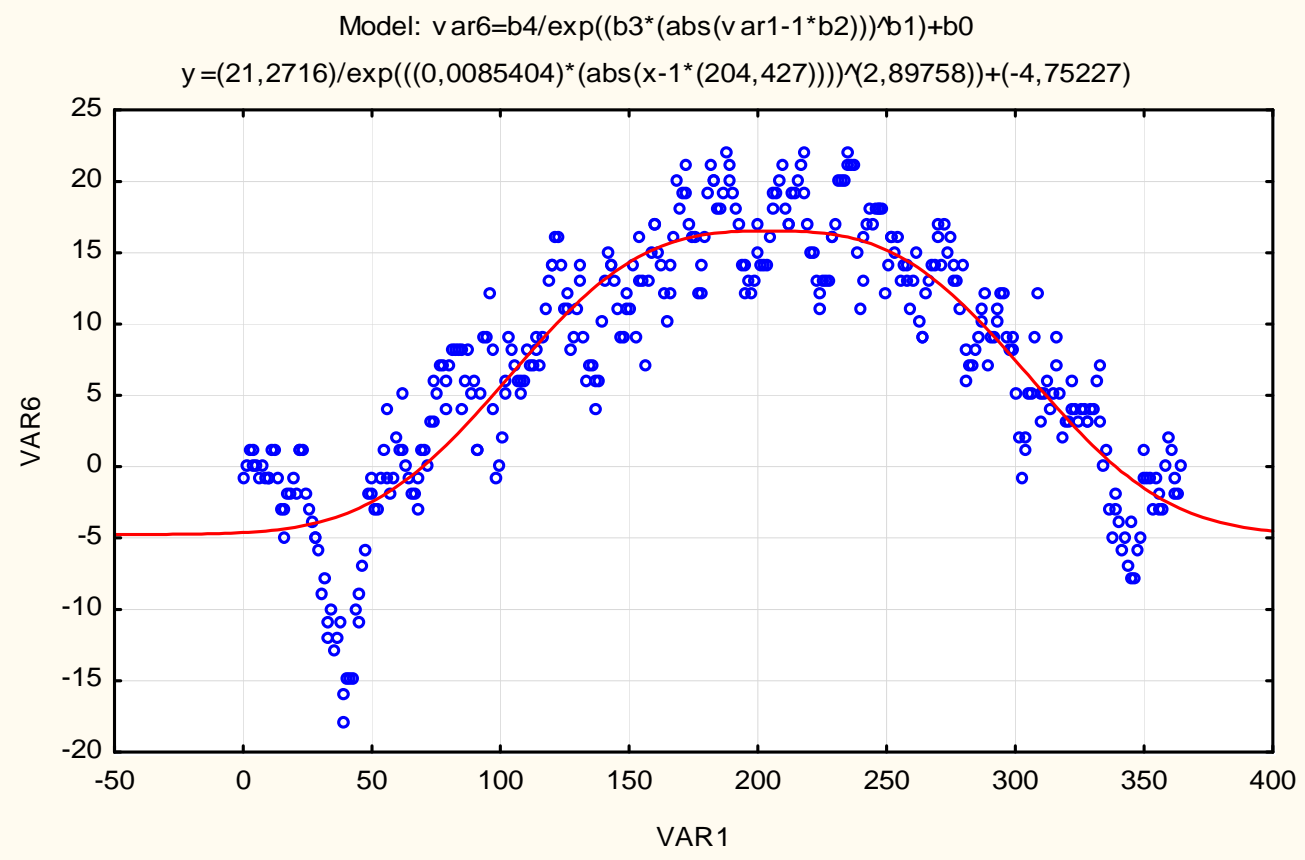

3. ábra: Hőmérsékleti minimum 2012

\begin{tabular}{|c|c|c|c|c|c|}
\hline \multirow[b]{2}{*}{$\mathrm{N}=361$} & \multicolumn{5}{|c|}{ 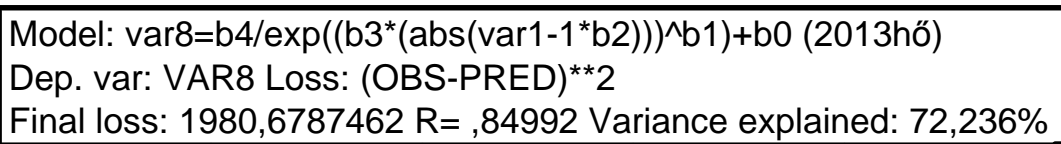 } \\
\hline & b4 & b3 & b2 & b1 & b0 \\
\hline Estimate & 15,09615 & 0,007528 & 204,9318 & 1,405378 & 0,368664 \\
\hline
\end{tabular}

4. táblázat: Hőmérsékleti differencia 2013

\begin{tabular}{|c|c|c|c|c|c|}
\hline \multirow[b]{2}{*}{$\mathrm{N}=361$} & \multicolumn{5}{|c|}{$\begin{array}{l}\text { Model: var5=b4/exp }\left(\left(\mathrm{b} 3^{*}\left(\mathrm{abs}\left(\operatorname{var} 1-1^{*} \mathrm{~b} 2\right)\right)\right)^{\wedge} \mathrm{b} 1\right)+\mathrm{b} 0(2013 \mathrm{~h} 0 ̈) \\
\text { Dep. var: VAR5 Loss: (OBS-PRED)**2 } \\
\text { Final loss: } 6861,6552101 \mathrm{R}=, 91966 \text { Variance explained: } 84,577 \%\end{array}$} \\
\hline & b4 & b3 & b2 & b1 & b0 \\
\hline Estimate & 35,50512 & 0,007927 & 203,8124 & 1,827248 & $-3,97838$ \\
\hline
\end{tabular}

5. táblázat: Hőmérsékleti maximum 2013

\begin{tabular}{|c|c|c|c|c|c|}
\hline \multirow[b]{2}{*}{$\mathrm{N}=361$} & \multicolumn{5}{|c|}{$\begin{array}{l}\text { Model: var6=b4/exp }\left(\left(b^{*}(\operatorname{abs}(\operatorname{var} 1-1 * b 2))\right)^{\wedge} \mathrm{b} 1\right)+b 0(2013 h o ̋) \\
\text { Dep. var: VAR6 Loss: (OBS-PRED })^{\star *} 2 \\
\text { Final loss: } 4043,1903132 \mathrm{R}=, 88752 \text { Variance explained: } 78,769 \% \\
\end{array}$} \\
\hline & $\begin{array}{l}\mathrm{b} 4 \\
\end{array}$ & b3 & b2 & $\mathrm{b} 1$ & b0 \\
\hline Estimate & 20,39401 & 0,008167 & 203,7588 & 2,216833 & $-4,29048$ \\
\hline
\end{tabular}

6. táblázat: Hőmérsékleti minimum 2013 
Model: $v$ ar8 $=\mathrm{b} 4 / \exp \left(\left(\mathrm{b} 3^{*}(\mathrm{abs}(\mathrm{v}\right.\right.$ ar1-1*b2) $\left.)){ }^{\star} \mathrm{b} 1\right)+\mathrm{b} 0$

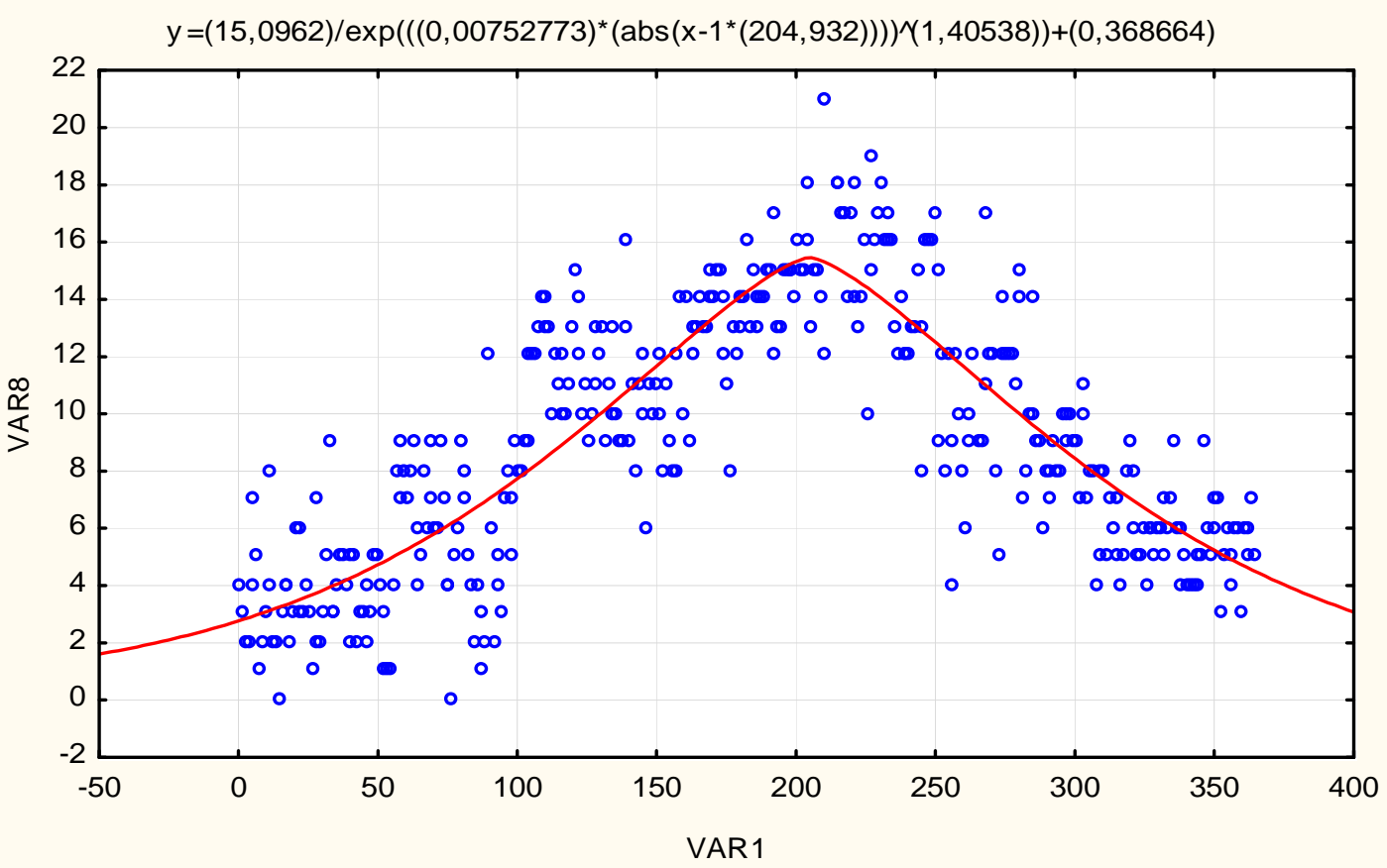

4. ábra: Hőmérsékleti differencia 2013

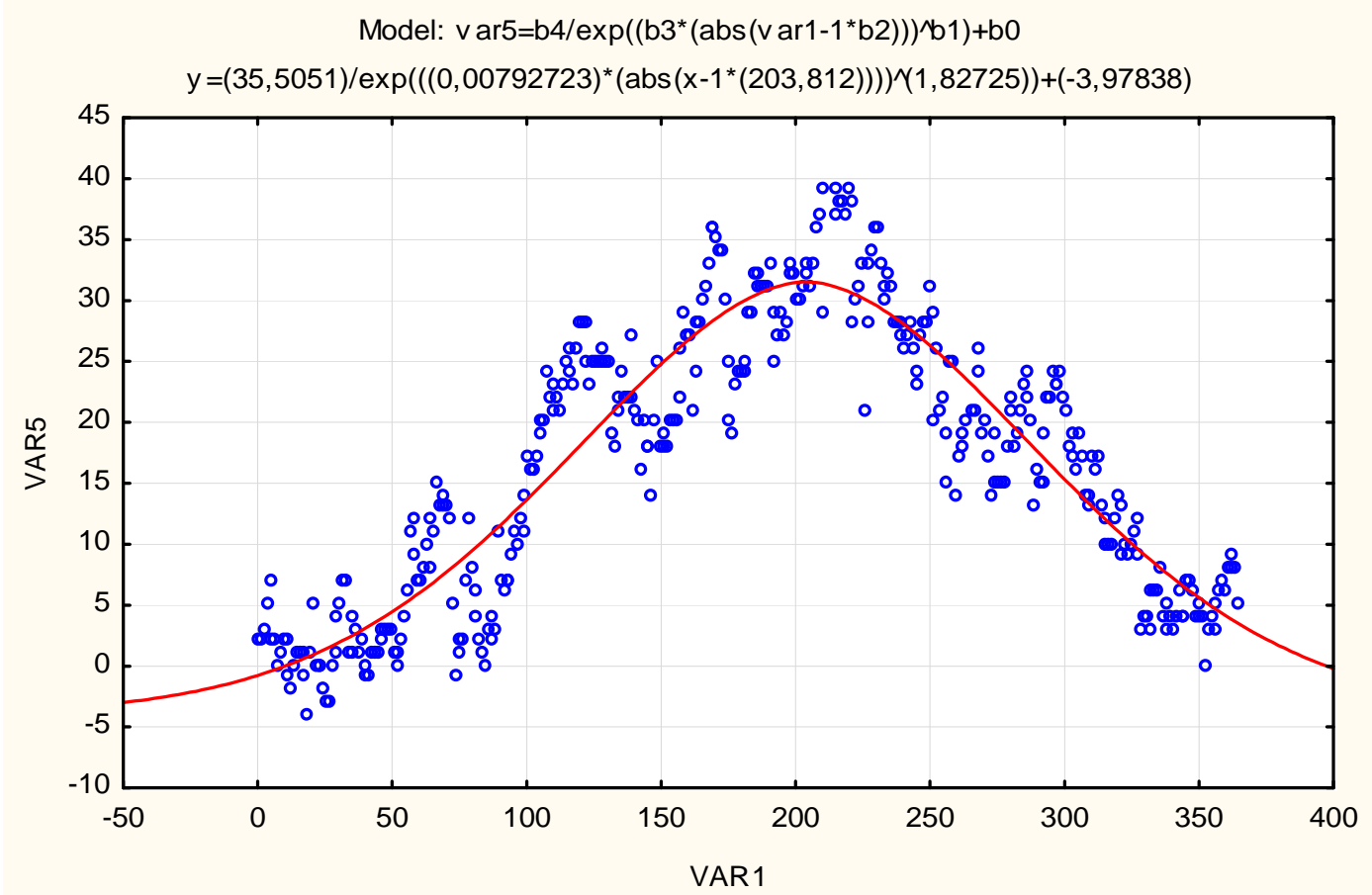

5. ábra: Hőmérsékleti maximum 2013 


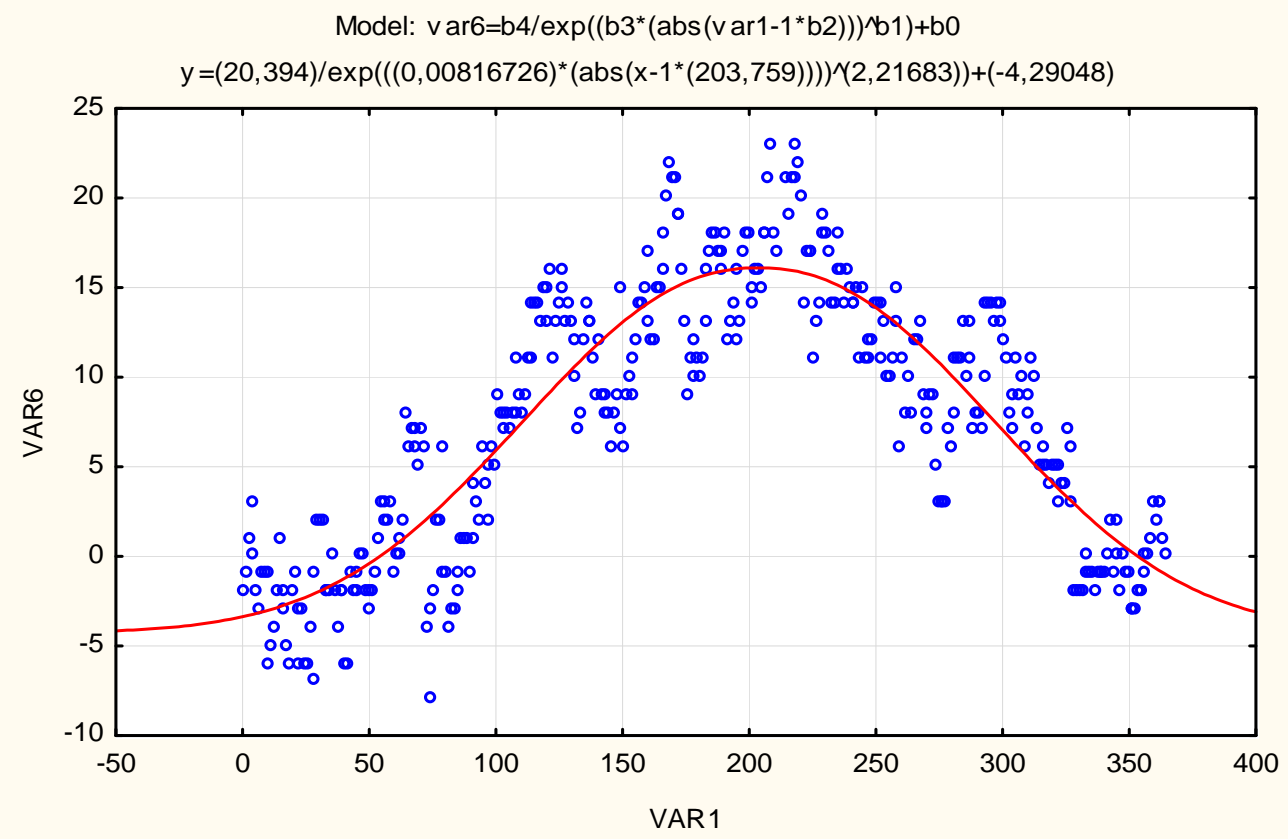

6. ábra: Hőmérsékleti minimum 2013

\begin{tabular}{|c|c|c|c|c|c|}
\hline \multirow[b]{2}{*}{$\mathrm{N}=365$} & \multicolumn{5}{|c|}{$\begin{array}{l}\text { Model: var8=b4/exp }\left(\left(\mathrm{b} 3^{*}\left(\operatorname{abs}\left(\operatorname{var} 1-1^{*} \mathrm{~b} 2\right)\right)\right)^{\wedge} \mathrm{b} 1\right)+\mathrm{b} 0(2014 \mathrm{hö}) \\
\text { Dep. var: VAR8 Loss: (OBS-PRED)*2 } \\
\text { Final loss: } 1678,7177417 \mathrm{R}=, 85303 \text { Variance explained: } 72,766 \%\end{array}$} \\
\hline & b4 & b3 & $\mathrm{b} 2$ & $\mathrm{~b} 1$ & b0 \\
\hline Estimate & 10,30769 & 0,009072 & 177,3426 & 2,322190 & 4,360774 \\
\hline
\end{tabular}

7. táblázat: Hőmérsékleti differencia 2014

\begin{tabular}{|l|c|c|c|c|c|}
\hline \multirow{2}{*}{$\mathrm{N}=365$} & \multicolumn{4}{|l|}{ Model: var5=b4/exp $\left(\left(\mathrm{b} 3^{\star}\left(\mathrm{abs}\left(\mathrm{var} 1-1^{*} \mathrm{~b} 2\right)\right)\right)^{\wedge} \mathrm{b} 1\right)+\mathrm{b} 0$ (2014hö) } \\
Dep. var: VAR5 Loss: (OBS-PRED)**2 \\
Final loss: 5707,6577813
\end{tabular}

8. táblázat: Hőmérsékleti maximum 2014

\begin{tabular}{|c|c|c|c|c|c|}
\hline \multirow[b]{2}{*}{$\mathrm{N}=365$} & \multicolumn{5}{|c|}{$\begin{array}{l}\text { Model: var6=b4/exp }\left(\left(b 3^{*}\left(\operatorname{abs}\left(\operatorname{var} 1-1^{*} \mathrm{~b} 2\right)\right)\right)^{\wedge} \mathrm{b} 1\right)+\mathrm{b} 0(2014 \mathrm{hö}) \\
\text { Dep. var: VAR6 Loss: (OBS-PRED })^{\star *} 2 \\
\text { Final loss: } 3768,4147268 \mathrm{R}=, 86875 \text { Variance explained: } 75,473 \%\end{array}$} \\
\hline & b4 & b3 & b2 & b1 & b0 \\
\hline Estimate & 17,93865 & 0,008111 & 199,9433 & 2,225050 & $-1,84529$ \\
\hline
\end{tabular}

9. táblázat: Hőmérsékleti minimum 2014 


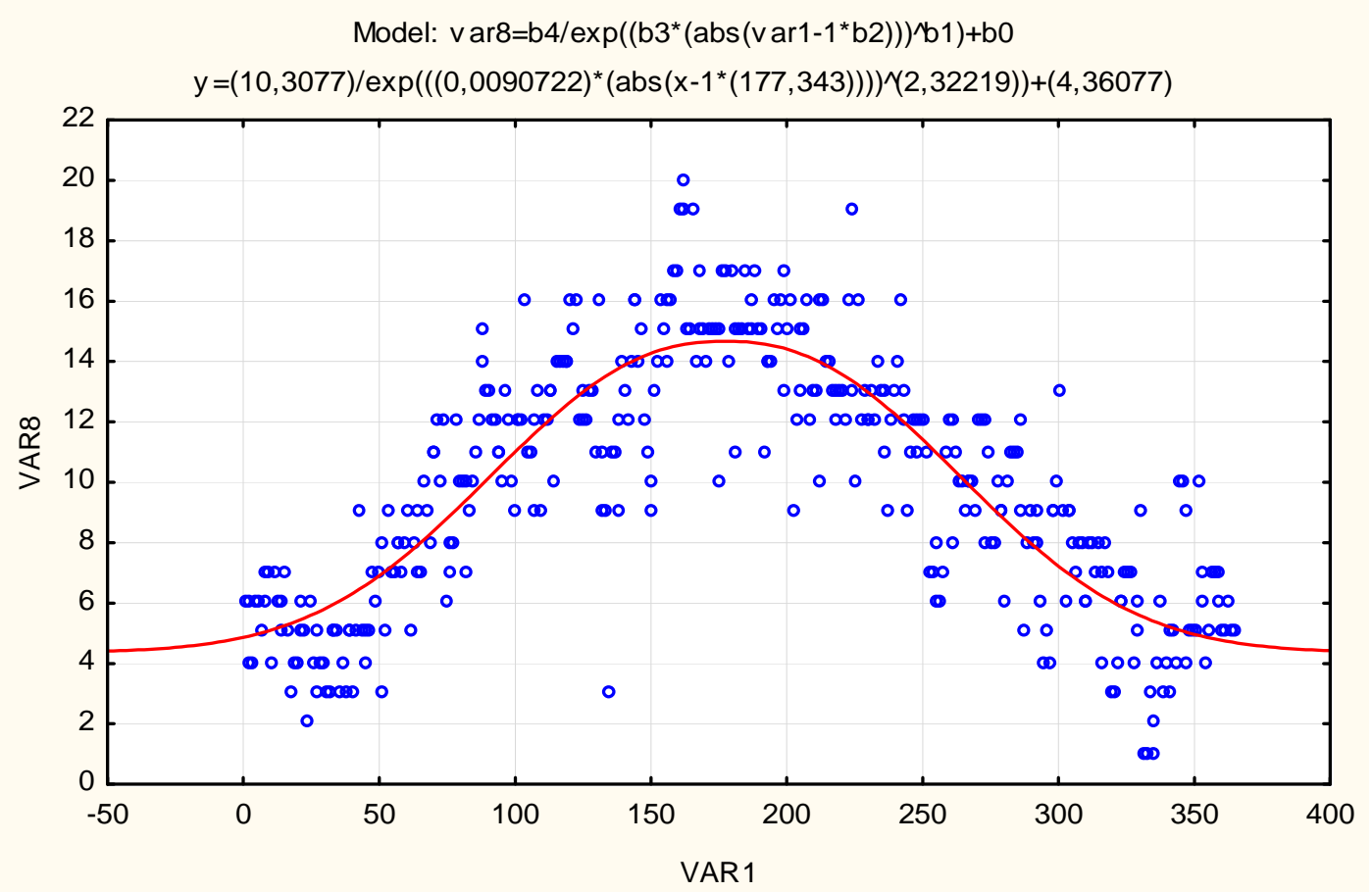

7. ábra: Hőmérsékleti differencia 2014

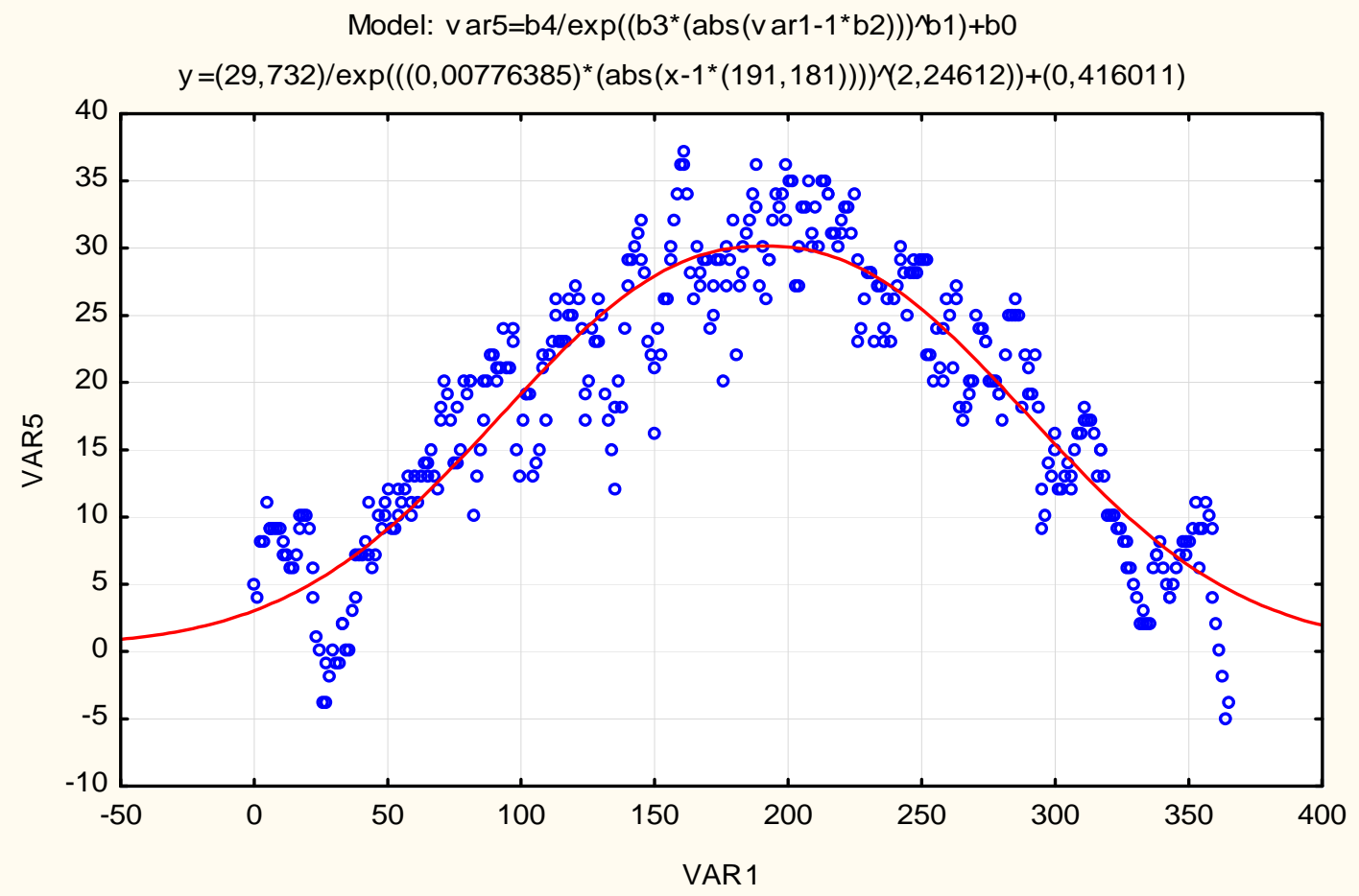

8. ábra: Hőmérsékleti maximum 2014 


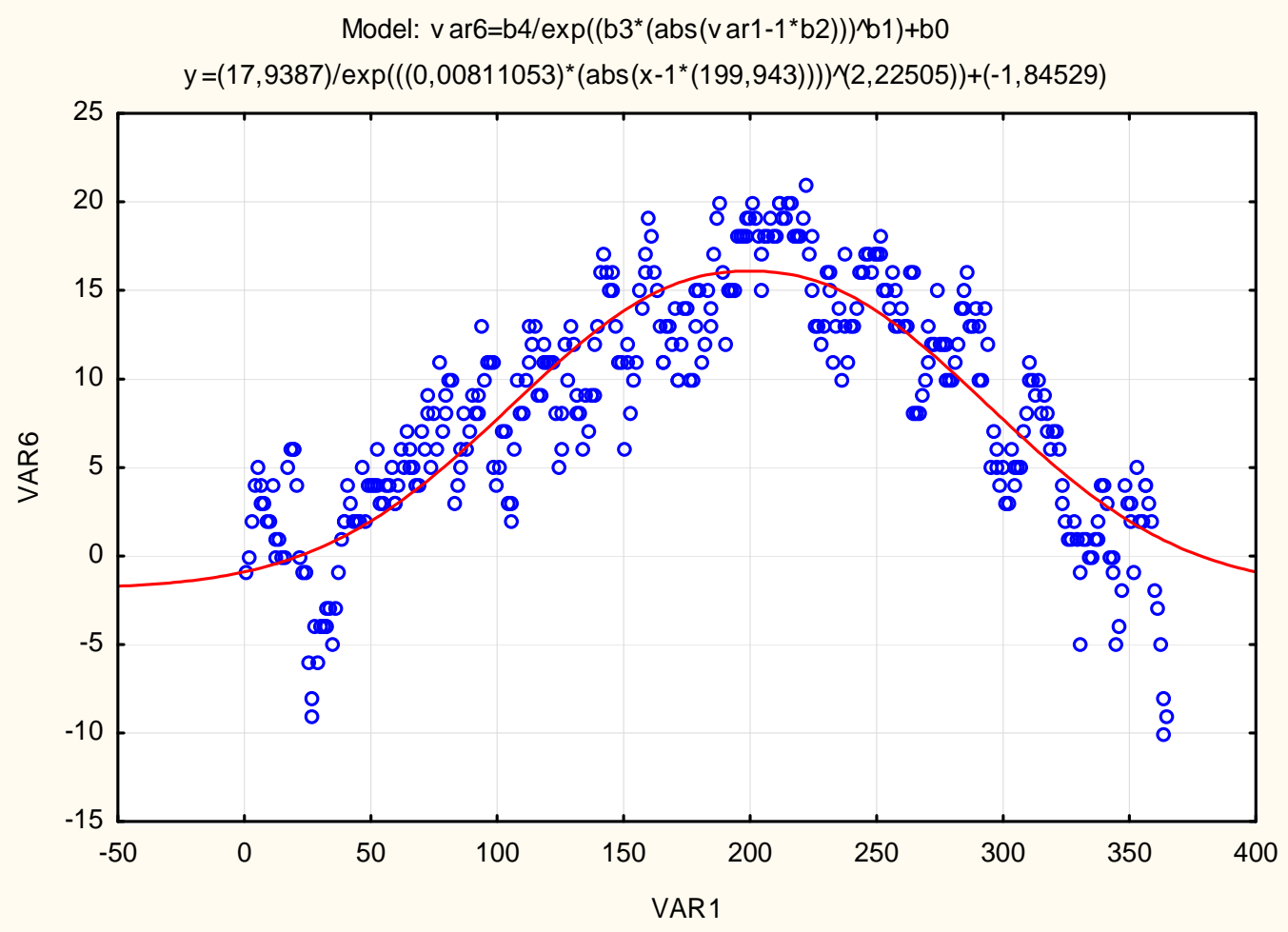

9. ábra: Hőmérsékleti minimum 2014

Function Plot

y2012 $=(7,86238) / \exp \left(\left((0,00801468)^{\star}\left(\operatorname{abs}\left(x-1^{*}(181,124)\right)\right)\right)^{\wedge}(4,2335)\right)+(3,89496)$

y2013 $=(15,0962) / \exp \left(\left((0,00752773)^{\star}\left(\operatorname{abs}\left(x-1^{*}(204,932)\right)\right)\right)^{\wedge}(1,40538)\right)+(0,368664)$

y2014 $=(10,3077) / \exp \left(\left((0,0090722)^{\star}\left(\operatorname{abs}\left(x-1^{*}(177,343)\right)\right)\right)^{\wedge}(2,32219)\right)+(4,36077)$

y2012 $=10,76$

y2013 $=14,47$

y2014 $=13,67$

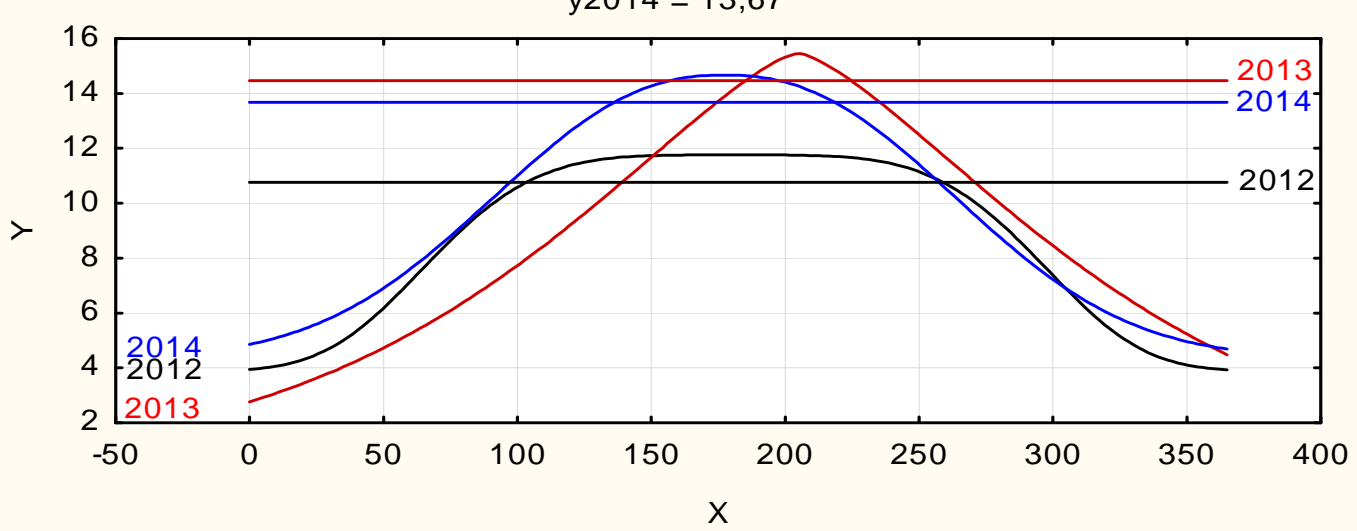

10 ábra: A három év összehasonlító grafikonja a hőmérsékleti differenciák menetére nézve, a nyert függvényalakokkal. 


\section{Function Plot}
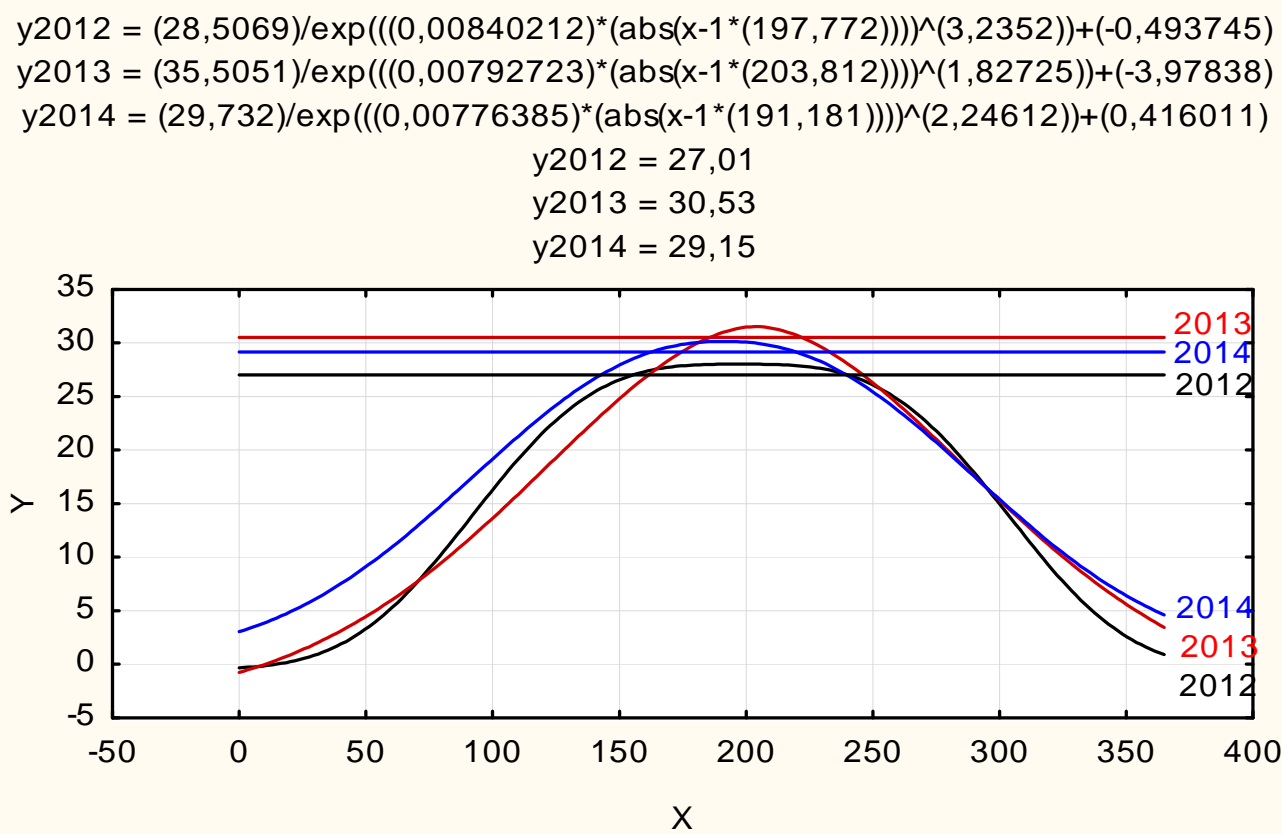

11. ábra: A három év összehasonlító grafikonja a hőmérsékleti maximumok menetére nézve, a nyert függvényalakokkal.

\section{2. Értékelés és elemzés}

Az alkalmazott függvényalak paramétereinek értelmezése az alábbi:

$b 4+b 0$ legnagyobb $y$ érték, $b 0$ legkisebb $y$ érték, $b 2$ legnagyobb $y$-hoz tartozó $x, b 1$ göbealakot meghatározó érték. $b 1=2$ esetén normál alak, ha $b 1<2$ hegyesedő, ha $b 1>2$ laposodó az alak. Az 1/b2 értéke a megfelelő illesztéshez tartozó vízszintes nyújtást kifejező mérték.

A regressziós eljárással nyert görbék közül a hőmérsékletmaximum menetét mutatók korrelációs együttható átlaga a legnagyobb $\mathrm{R}=0,92$, a hőmérsékletminimumra vonatkozóké $\mathrm{R}=0,88$, a hőmérsékletdifferenciára vonatkozóké $\mathrm{R}=0,84$.

A könnyebb és gyorsabb értékelhetőség, összehasonlíthatóság és eltérési kimutathatóság érdekében az alapvető adatok bemutatására az alábbi táblázatban kerül sor, feltüntetve a görbemaximumtól lefelé legfeljebb $1 \mathrm{C}^{\mathrm{o}}$-kal eltérő tartományokat is, mely számértékek természetesen a regresszióval nyert függvénygörbék megfelelően kerekített paraméterei. A táblázat rövidítései a következők:

$t(\max )=a z$ év hőmérsékletmaximumához tartozó időpont az év elejétől számolt napokban.

$h(\max )=$ az év hőmérsékletmaximuma celziusz fokokban.

$k(\max )=a z$ év hőmérsékletmaximum felső tartománya napokban 1 celziusz fok lefelé eltérés figyelembevételével.

$t d(\max )=$ az év hőmérsékletdifferencia maximumához tartozó időpont az év elejétől számolt napokban.

$h d(\max )=$ az év hőmérsékletdifferencia maximuma celziusz fokokban.

$k d(\max )=$ az év hőmérsékletdifferencia maximum tartománya napokban 1 celziusz fok lefelé eltérés fegyelembevételével. 


\begin{tabular}{|c||c|c|c|c|c|}
\hline \multirow{2}{*}{ év } & $\mathrm{t}(\max )$ & $\mathrm{h}(\max )$ & $\mathrm{k}(\max )$ & $\mathrm{R}$ & $b 1$ \\
\cline { 2 - 6 } & $\mathrm{td}(\max )$ & $\mathrm{hd}(\max )$ & $\mathrm{kd}(\max$ & $\mathrm{R}$ & $b 1$ \\
\hline \hline \multirow{2}{*}{2012} & 198 & 28,01 & 86 & 0,924 & 3,23 \\
\cline { 2 - 6 } & 181 & 11,76 & 156 & 0,839 & 4,23 \\
\hline \hline \multirow{2}{*}{2013} & 204 & 31,52 & 36 & 0,920 & 1,83 \\
\cline { 2 - 6 } & 205 & 15,47 & 40 & 0,850 & 1,40 \\
\hline \hline \multirow{2}{*}{2014} & 191 & 30,15 & 57 & 0,915 & 2,25 \\
\cline { 2 - 6 } & 177 & 14,67 & 82 & 0,853 & 2,32 \\
\hline
\end{tabular}

10. táblázat: Összefoglaló táblázat

\section{KÖVETKEZTETÉS}

A regresszióval nyert görbék összefoglaló ábráit (10. és 11. ábra) is értékelve, a táblázat adatait statisztikai jelleggel elemezve a következő megállapítások tehetők.

- A 2014-es év napi hőmérsékletmaximumot és napi hőmérsékletdifferenciát mutató görbealakja áll legközelebb a Gauss görbéhez a $b 1=2,25$ ill. 2,32 érték miatt, ezért ezen év hőmérséklet menete statisztikai értelemben normálisnak tekinthetö.

- A 2012-es év napi hőmérsékletmaximum felső tartománya $k(\max )=86$ nap, napi hőmérsékletdifferencia maximum tartománya $k d(\max )=156$ nap, ami a $b 1=3,23$ ill. 4,23 értékkel együtt azt jelzi, hogy ezen évben eltérően hosszú ideig volt statisztikailag nyári évszak.

- A 2013-as évben az előző évhez képest a $k(\max )=36$ nap, a $k d(\max )=40$ nap rövid idejü volt $b 1=1,83$ ill. 1,40 érték mellett, ami egyértelmüen mutatja, hogy a tavaszi, nyári és őszi évszak gyorsan változó jelleggel rendelkezett. Ugyanekkor a kiemelkedően magas $h(\max )=31,52 \mathrm{C}^{\circ}$, és $h d(\max )=15,47 \mathrm{C}^{\mathrm{o}}$ időkéséssel $t(\max )=204$-dik nap, $t d(\max )=205$ dik nap jelent meg.

- A vizsgált három év időbeli hőmérsékletérték változási menete különböző, viszonyítási alapnak a nyert paraméterek alapján a 2014-es év rendje tekinthető. A 2012-es és 2013as év értékei viszont jelzik, hogy a klímaváltozás elemzéséhez érdemes még néhány éves időszak adatainak megfelelő módszerrel való feldolgozását is elvégezni.

A felsoroltak és bemutatottak alapján megállapítható, hogy a regressziós eljáráshoz alkalmazott egyedileg szerkesztett függvény jól értékelhető paramétereket szolgáltat meteorológiai adatok feldolgozásához és elemzéséhez.

\section{Irodalomjegyzék}

[1] Csanády V.: Számítógépekre konvertált nem hagyományos regressziós eljárások faipari - erdészeti kutatási és műszaki problémákhoz. Műszaki doktori értekezés, Sopron, EFE, (1993).

[2] Orbay L.: A többváltozós regressziószámítások alapja és fagazdasági alkalmazása, EFE, Sopron, (1990).

[3] D. R. Pelz, : Einführung in die biologische Statistik für Forststudenten. Teil II.Freiburg, (1989). 